\title{
THE LOCAL WISDOM OF KEI PEOPLE AS A SOURCE OF LEARNING LOCAL HISTORY TO STRENGTHEN STUDENTS' SOCIAL COHESION
}

\author{
Agustinus Ufie ${ }^{1}$
}

\begin{abstract}
Local culture as a social capital in the life of Kei people should always be established particularly for young generation through education. Now the Kei People is being introduced by modern culture as a reflection of city life, it tends to precede individualistic as well as materialistic which affect the occurrence of violence, brawling or gang fighting, hoodlumism, and even terrorism which have degraded moral values of nation. Conserving values of culture as the local wisdom of Kei people is very important not only to control violence, brawling or gang fight between groups, individualism, and hedonism which have been dominating the local people life, but also because this region have ever been stricken by social conflicts. Rebuilding as well as retighten social solidarity and cohesion through learning history sourced from values of local wisdom are indeed required. Social Cohesion is an adhesive uniting society, developing sociological harmony and spirit along with commitment to achieve mutual goals. Reviving and conserving values of local culture which are applied as a source of learning local history are absolutely imperative in order to eliminate even stop various violence, revive conflict, brawling or gang fight, and drugs abuse among young generation.
\end{abstract}

Key words: Local Wisdom, Kei people, local history, social cohesion

\footnotetext{
${ }^{1}$ Agustinus Ufie, lecturer in the Study Program of History Education in University of Pattimura, Ambon. For academic interest, the author can be contacted through the office address: Jendral Achmad Yani Street 9, Ambon.
} 


\section{Introduction}

Conflicts nuanced ethnic, religion, race (SARA), violence, (hoodlumism, motor gang, brawling or gang fight), and terorism which happen in some regions in the United Nation of Republic of Indonesia nowadays, show the disappearance of national identity which is well known for its hospitality, tolerance, peace lovers, unity and integrity as well as its fraternity. The violence and the social conflict will continuously happen if we are not able to discover appropriate ways to the solution of eliminating or even to stop any kinds of happening violence and conflict.

Elevating and conserving cultural values of culture existing and developing in the local society as a local wisdom are one of ways to decrease even more to solve various conflicts happend nowadays. Prof. Nasaruddin Umar, Vice Religion Minister of Republic Indonesiain a National Seminar of 'Religion and Pluralism in Maluku' in 2011 states that local wisdom growing in various regions can be advantaged to alleviate or eliminate conflicts because Indonesian society prefer to a culture approach in solving various matters. (http://indonesia. ucanews.com/2012/01/31/kearifan-lokaldapat-kurangi-konflik-agama/).

Therefor hence, local wisdom in social life of Kei people which is full of values such as tolerance, unity and integrity, mutual respect, and fraternity should hereditarily be established and maintained from generation to generation through various ways. As it was stated by Koentjaraningrat said $(1989 ; 190)$ that the values of culture are social fact existing the society which is hereditarily inherited from a generation to generation through the process of socialization and social orderliness which 'enforce' someone to respect and obey the norms prevailed in the society in which the individual live and interact with others. Thus, the continuity of a culture highly depends on the extent of noble values of the culture itself if it is firmly grasped and inherited well by its proponents.

Conserving the cultural values of culture as a local wisdom of Kei people becomes very essential not only because of the violence, brawling or gang fight among groups, individualism, and hedonism which is more and more taking control over social life, but also because of this region which has ever been stricken by social conflicts some time ago. Rebuilding and retightening social solidarity and cohesion among students through learning from local wisdom values are imperative because social cohesion is an adhesive which unite the society, build harmony and sociological spirit and commitment to achieve mutual goals, stated by Nat J. Colletta at al. (2001;2)

As it was revealed in the study of Kondrad Huber et.al (2004;7) that social cohesion sourced from local wisdom values are required to concoct peace, harmony, and conformity in social life post-conflict. Because the effort of reconcilement and development are supposed to affect social dynamics, it is expected to bring positive transformation. The transformation can be a kind of reduction of violence and conflicts, a more positive attitude from individuals, respect of differences, and peace lovers. Furthermore, according to Kondrad that particularly youth and teenagers can be classified as an adequately important group, if it is correlated with social cohesion, conflicts, violence and reconciliation. 
Therefore, the local wisdom as an identity of local people are laden of values and social regulations which become a guidance in arranging life interaction among society and it should precisely be implemented. According to Gobyah (Ernawi, 2010; 2), local wisdom is defined as a truth which has become a tradition that monotonious existed in a region. Henceforth, the diversity of tribes, cultures, religions and languages in Indonesia must be throne properly because, strictly speaking, the diversity is a strength yet, it is also a source of conflicts. As stated by Hamid Hasan $(2012 ; 104)$ that:

The diversity of culture in one side is an opulence of country but in the other side it can be a source of disadvantageous conflicts. Education should be able to develop students' potency so that they can transform the diversity of culture so previously a potential source of conflict becomes a potential source of productive cooperation and a source of inspiration towards other cultures.

Thus, the social and cultural pluralism existing in whole regions in Indonesia are needed to be developed and to maintained. Local culture as a social capital in the social life of Kei people should continuously be developed especially towards young generations through the education process. Because of the existence of introduction of modern culture as the reflection of city lives, it tends to precede individualism and materialism bearing to the violence, brawling or gang fight, hoodlumism and even terrorism which have degraded moral values of nation culture.
Social conflicts which have ever occured in Maluku some time ago, or violence (freemanism) of a group of youth which behalves of Kei for instance, had conducted negative point of views toward Kei people. Actually this stigma is not correct if the society is able to make values of local cultures or local wisdom as a guide and guidance in their lives. Reviving and conserving the values of local culture to the young generations especially to the students are very vital to strengthen their sense of nationality, where these cultural values can be appllied as a source of learning local history to eliminate and even to stop any violence, conflicts, brawling or gang fight, drug abuse which circle around the young generation particularly among the pupils.

The education of local history as a part of national history education in the system of national education is beneficial as a tool to identify students' identity as well as a filtration towards negative impacts which is growing and developing as a result of modernization. Along with that, Hamid Hasan (2012; 108) declares that learning process of education is aimed to establish students' capability to recognize their identity and their country's identity. Education of History will araise emphatic awareness, tolerance toward others, mentality to imagine and be creative among students themselves.

The emphatic awareness to others will grow togetherness and interrelatedness or solidarity among them. In addition to this, tolerance will make students comprehend the values of pluralism, democratic spirit, mutual respect, responsibility and commitment so that the history education is expected to generate collective memory awareness of our nation's past experience. 
Consequently, learning history is not only merely about learning past historical events but also learning lofty ideal values which grow and develop among the society, that can become a source of motivation, for student for them support and guidance in managing and arranging future life in various field like social, culture, politic, law and economy. As it was stated by Mulyana dan Gunawan (2007: 1) that :

Learning history is fundamentally learning about society lives. Various life aspects can be learnt through learning the history whether it is correlated with aspects of social, political culture, economy and other life aspects. The important feature of learning the society as a focus of histirical study is seeing the society as something changeable as the time goes on. Besides the time aspect, in learning where the life of society, it is also obvious that historical is closely correlated with spaces, places where life society is investigated. The spaces aspect can be seen in a more extended context, national history or a narrower context, local history.

Therefore, the role of teaching national history is very important to form local identity to sustain nation's integrity. In a resereach entitled "Learning Based Multicultural Approach and the Local, National, Global Prespective in Nation's Integrity" conducted by Supardan (2004;262) reveals that learning local history is neccesary to be introduced to the students to recognize their local identity as well as respect the identity of their ethnic and others' existing in Indonesia. Teaching local history can be viewed as an implemented solution by taking along the students to identify history from their own surrounding which is called living history.

Through the learning of local history sourced from local culture is absolutely to make the students aware and understand the real situation of their surrounding living history. The students are persuaded to identify, comprehend and to enable them to actualize culture and tradition of the local society in their life as a part of the intended society. Making the students' surrounding as a learning source of local history is aimed in order to grow nation and character building through a process of institutionalization of positive values such as values of local culture heritage, heroism, solidarity, and nationalism. It is parallel with what Agus Mulyana dan Restu Gunawan stated (2007;2) that :

\begin{abstract}
Historic subject contains good enought values. The values meant here are not merely about general nationality values like nationalism, patriotism, democracy, etc. The values that must be grown and developed are values which own local wisdom, it is a value growing and developing in the students' surrounding.
\end{abstract}

Therefore, history subject is supposed to be reconstructed by using new paradigm of new history which means in the process of teaching learning history, the teachers are absolutely required to be able to extend learning materials where the teachers are not only based their teaching on national history but also on developing local wisdom of the students' living history as a source of history learning. As it was revealed by 
Douk (Widja, 1998;5) that the learning of local history is easier to be comprehended by the students because it is correlated with their living surrounding.

\section{The Local Wisdom of Kei People}

Etymologically, wisdom is defined as one's capability of using his thought to determine and decide an event, an object or a situation. Meanwhile, local shows an interaction space where the event or the situation happend. Henceforth, local wisdom is substantially a norm prevailed in a society where the truth is convincible and becomes a reference in daily acts and behavior (Novio, 2012;14).

Furthermore, local wisdom as conveyed by Gobyah (Ernawi, 2010;2), is a truth which has been a tradition or hereditary legacy in a region. According to Ridwan (Ernawi, 2010;3), Local wisdom is comprehended as a human's effort using their cognition to act and behave toward something, an object or event occurred in a certain circumstance.

Meanwhile, Sutarto (2006;1) mentioned that local wisdom or local learnedness (tradition) utilized as a guidance in social life is a central part of tradition. Tradition is a hereditary habit or custom reflection the existence of its proponents. Local wisdom is an attitude, a view point, and a capability of a society to manage their religious and materialized environment, which give the community endurance and keep growing spirit in the region where the community live. In other words, local wisdom is creative solutions or answers toward situation of geograficgeopolitic, historic, local and situational (Saini, 2005).
Local wisdom is an identity of local society which is full of values as a guide and guidance of social life. Therefore, according to Mutakin $(2005 ; 43)$ local wisdom is :



Local wisdom as conveyed above truly contains values as a guidance in life together with the society. Therefore, Fraenkel $(1977 ; 17)$ defined values as a standard of attitude, beauty, justice, truth and efficiency which unite human and should appropriately be performed and maintained. Values possess essences which adhere to something meaningful for human life. Meanwhile, Budiyono (2007;75) explains that the quality of something beneficial for human life for both body and soul. In human life, values are made as a foundation, reason or motivation to behave and to act. Values are material and immaterial nature. Immaterial values are not concrete or cannot be caught by five senses but it can be felt. A more concrete tangible from the concept of immaterial values in social life is what is known as norms, the social order of society.

People who live in Kei island generally revere their culture or their local tradition that is hereditary maintained. The values of honesty, harmony, love, mutual respect and diversity respect are always becoming 
a postulate in the attitude and activities of the local society. However, recent reality shows that big current of modernization has slowly brought the local society life into chaos. This can be seen from the increasing attitude of primordialism, egoism, hedonism, and promiscuity which affect the social harmonization.

To strengthen social life of our society as a nation and more than that, as God's creatures, introducing ideal nation's values among local society as a unifier, life binding are very important to be encouraged in the social life. The values of this local culture are the soul of the local culture and become a foundation of every culture as well as a treasury of national culture in their region.

The tradition of Ain Ni Ain in Kei social life has become a philosophy in Kei people's life in guiding, uniting, and adhering the diversity existing in the society like religion, ethnicity, social strata, and economy. The tradition of Ain Ni Ain as a local wisdom that can be defined as a sense of belonging one to another, a realization of fraternity (we are all brothers). This life philosophy is precisely similar with our nation's philosophy, Bhineka Tunggal Ika.

The values contained inside the Ain $\mathrm{Ni}$ Ain philosophy like self-sacrifice, relativity, fraternity, struggle, equality, mutual assistance, mutual respect, mutual sense of belonging, and love, have guided the way of Kei people's life which is peaceful in the spirit of fraternity. The values of local wisdom should be extended and stimulated as well as maintained because those local wisdom values become social adherences which are strongly beneficial to stifle negative effects of modernization. In addition to that, the local wisdom of
Ain Ni Ain tradition is believed to be very potential in solving various social disputes such as brawling or gang fight, conflicts and other social disputes. Therefore, local wisdom as an society's identity should always be extended and stimulated through various ways in many chances. Implementing lofty values contained in the local society tradition and culture as a local wisdom in education is important and precise because education is a process to form students' attitude and character of the young generations as the heir of the nation's in the future.

\section{Learning Sources of Local History}

Learning sources are any places or suroundings, anythings, and any people having information which can be used as a vehicle for students to perform a process of behavior changes, (Madjid, 2008: 170). Meanwhile, Edgar Dale (in Rohani, 1997;102) declared that learning sources are experiences which are fundamentally extended, as life which copes anything sensible which bears learning moment, the behavior changing to a more perfect one that based on the goals determined previously. Learning sources according to Rohani $(2004 ; 61)$ are every effort which is used to the importance of teaching activities both directly and indirectly, both in and out of the students (environment) which can complete them while teaching process is in progress.

In the context of learning local history, environment and values of local culture as the local wisdom of Kei people can be made as learning sources. The learning sources resourcing from social culture and reflected through students' daily activities, social life of the society, and also various other 
activities which are believed to enliven and to toughen the social cohesion of young generations especially the students. Along with that, Nasution, (Fathurrohman and Sutikna, 2007;16) state that learning sources can becomes from the society and their culture, the development of science and technology as well as students' needed. Similarly, Robert Douch (Mulyana and Gunawan, 2007;1) asserts that through learning history, the students are expected to be able to see directly the real life, not materials of study which are far away from the reality. Even good learning can come from the students' daily experience. Emotional propinquity of students with their environment is a worthy learning source to the learning process in their class.

Fundamentally, local history is a historical study which still talks about any events in a regional level. Local history is not an isolated study which avoids extended or national historical study. As said by Widja and highlighted by Mulyana and Gunawan in a book entitled Sejarah Lokal Penulisan dan Pembelajaran di Sekolah (Local History: Writing and Learning at Schools) $(2007 ; 02)$ that the study of local history is about society's life or particularly a community in a certain neighborhood in its development dynamic in various human life aspect. Finberg who is well-known as the founder of Mazhab Leicester in a study of Local History in English, states that local history is the "Origin, Growth, deterioration, and collapse period of the localsociety".Apressuretoward community and determination of history rhythm are not meant to expect the "deterioration" and "the collapse" (Abdullah, 1990;18).
According to Lapian (Supardan, 2004;111), who state that the role of events occurring tin local history fundamentally possess two roles. The first, there are events which will permanently have local meaning, and the second, there are some events which have more extended meaning. Henceforth, local history should principally be learnt because local history has a big chance to be used as correction toward history generalization which is made in the writing of national history. Mahoney and Douch (Supardan 2004;111) clearly showed the superiority of teaching local history compared to teaching conventional history where teaching local history has an capability to take students to the real situation of their neighborhood. Teaching local history enable the students to break through and bridge them to what actually happen to the students themselves and also to their neighborhood life where they live.

Learning local history from their neighborhood both events and society activities are the most important thing to determine local-identity of the society. Along with that, Abdullah (1990;11) stats thatlocalhistoryisacademicallytoenlighten everything enclosed by the darkness of era, which has been darkened and swallowed, and to remind back everything which has been forgotten as time passed by.

\section{Social Cohesion among the Students}

Establishing social cohesion is an important element in managing mutual social life well. Furthermore, social cohesion is also necessary in establishing peace, harmony and conformity in the 
social life post-conflicts, where efforts of peace and development are expected to be able to affect the social dynamic so that it can bring positive changes. Those changes can be in the form of the decreasing of violence and conflict, individual's more positive attitude, respect of diversity and peace lover.

As stated by Colletta at al. $(2001 ; 2)$ that social cohesion is an adherence which unites the society, builds the harmony and stimulates the spirit of society as well as commitment to achieve mutual goal. Therefore, Siddique (Kondrad et.al, 2004) assumed that social cohesion is a fundamental requirement to a society. Furthermore, as stated by European Council (2004) that social cohesion is the ability of a community to guarantee their members' wealthy, to minimize the diversity and to avoid the polarisim. Cohesive society is a community consisting of free individuals who support each other to achieve mutual goals democratically.

By the emphasis of the social cohesion development, it can help to establish trust, association among groups, and communicative entanglement among separated groups due to violence, to precede their group's importance, and to solve other social problems. Building social cohesion is aimed to bridge the cooperation, mutual understanding, and precedence of mutual goal to maintain mutual peace. Similarly, Ritzen et al. (2000;2448) states that social cohesion is a circumstance where a group of people (in one geographical region) show their ability to collaborate and to bear good climate for good changes.

There are five principle dimensions of social cohesion found from four policy document of French and Canada government, OECD and some communities as conveyed by Berger and Schmitt (2000;20-21), they expose five principle dimensions from social cohesion that cope with (a) togetherness-isolation (mutual values, identity, sense and commitment), (b) participation-ignorance (equal chances to get access), (c) participationuninvolvement(in cases of politic, economy, social and culture),(d) acceptance-rejection (respect and tolerance of diversity in plural society) dan (e) legitimacy-illegitimacy ( toward institution which pay roles as a mediator in the conflict of plural society). Referred to the above overview, Ritzen et al, (2000;2448) then conclud that there are two principal dimensions of social goals of social cohesion; they are, first, is elimination of the diversity, injustice, and the social ignorance, and second, emphasis on strengthening connection, interaction, social adherence, more or less to cope fundamental concept similar with social capital.

Therefore, according to Kondrad et. al $(2004 ; 7)$ the establishment of social cohesioncanhelptoextendtrust, association among groups, and communicative entanglement among separated groups due to violence. Therefore, the establishing social cohesion results in bridging cooperation, mutual understanding, and precedence of mutual importance can become a foundation to maintain continuous peace and togetherness.

\section{Conclusion}

Thevalues within AinNiAin philosophy, like willing to sacrifice, relativity, fraternity, struggle, equality, mutual assistance, mutual respect, mutual sense of belonging, love each other, have guided the life of Kei 
people who live in peace and in the spirit of fraternity. These local wisdom values must be grown, stimulated and conserved because the local itself can be a strong social adherence to stifle negative impacts of modernization.

Learning local history sourced from neighborhood life both events and activities of local society is the most important thing to find society's local identity. Teaching local history can break through and brides what actually happen to the students themselves along with their neighborhood life where they live. Establishing and strengthening again the social solidarity and cohesion through learning history sourced from local wisdom values are absolutely required. Social cohesion is an adherence in uniting the society, building the harmony and socializing spirit as well as commitment to achieve mutual goals.

\section{REFERENCES}

Abdullah, T. (1990). Sejarah Lokal di Indonesia. Yogyakarta: Gadjah Mada University Press.

Berger and Schimitt. (2000). Social Cohesioan as on Aspect of the Quality of Societies: Concept and Measurement. EuRoperting Working Paper.No. 14,

Budiyono. (2007). Nilai-Nilai Kepribadian dan Kejuangan Bangsa Indonesia. Bandung: Alfa Beta.

European Committee for Social Cohesion. (2004). "Revised Strategy for Social Cohesion".

Fraenkel, J.R. (1997). How to Teach Abaout Values; An Analytic Approach. New Jersey; Prentice-Hall, Inc,
Hasan, S.H. (2012). Pendidikan Sejarah Indonesia, Isu dalam Ide dan Pembelajaran. Bandung: Rizqi Press.

Khun, T. (2005). The Structure of Scientific Revolutions. Bandung: Rosdakarya.

Koentjaraningrat. (1990). Pengantar Ilmu Antropologi. Jakarta: Rineka Cipta.

Koentjaraningrat. (2004). Kebudayaan Mentalitas dan Pembangunan. Jakarta: Gramedia Pustaka Utama.

Mulyana, A and Gunawan, R. (2007). Sejarah Lokal, Penulisan dan Pembelajaran di Sekolah. Bandung; Salamina Press.

Mutakin, A. (2006). Individu, Masyarakat dan Perubahan Sosial. Bandung; FPIPS - UPI.

Mutakin, A. (2005). Nilai-Nilai Kearifan Adat dan Tradisi di Balik Simbol (Totem) Kuda Kuningan. Bandung: FPIPS - UPI.

Nat J. (2001). Social Cohesion and Conflict PreventioninAsia:Managing Diversity through Development. Washington D.C. The World Bank, 2001.

Ritzen. (2000). Good Politicians and Bad Policies: Social Cohesion, Institutions and Growth. World Bank.Policy Research Working Paper.

Stavenhagen, R. (1986). Problems and Prospects of Multiethnic State. Tokyo: United Nations University Press.

Supardan, D. (2000). Kreativitas Guru Sejarah dalam Pembelajaran Sejarah" (Studi Deskriptif-Analitis terhadap Guru dan Implikasinyauntuk Program Pengembangan Kreativitas Guru Sejarah Sekolah Menengah Umum di Kotamadya Bandung). Bandung: UPI, Tesis, 
AGUSTINUS UFIE,

The Local Wisdom of Kei People as a Source of Learning Local History to Strengthen Students' Social

Cohesion

Syafa'at, R. (2008). Negara Masyarakat dan Kearifan Lokal. Malang In-Trans Publising.

Umar, N. "Agama dan Pluralisme di Maluku”,http://indonesia.ucanews. com/2012/o1/31/kearifan-lokaldapat-kurangi-konflik-agama/ (accessed, February, 6th 2013).
Widja, I.G. (1989). Sejarah Lokal suatu Perspektif dalam Pengajaran Sejarah. Jakarta : Direktorat Pendidikan Tinggi, Departemen Pendidikan dan Kebudayaan. Proyek Pengembangan Lembaga Pendidikan Tenaga Kependidikan. 